\title{
Unprecedented economic attack on Sub-Sahara African economies: coronavirus
}

\section{How severe is the perceived slump?}

\author{
Nchimunya Ndiili ${ }^{1}$ (0) \\ Published online: 25 May 2020 \\ ๑) Springer Science+Business Media, LLC, part of Springer Nature 2020
}

\begin{abstract}
This paper postulates the impact of coronavirus on Sub-Saharan African (SSA) economies and resilience to the pandemic. Relief measures instituted by World Bank Group (WBG) and International Monetary Fund (IMF) to help in the prevention, detection and treatment of coronavirus amidst SSA non-monetary measures and business support interventions are highlighted. The underlying economic challenges likely to impede WBG and IMF relief measures in SSA such as health infrastructure and resource deficiency, unsustainable high debt levels and drought effects due to climate change are analysed. Ranking the inadequate doctor-to-population ratio from 2015 to 2017, SSA ratio stood at less than 1 per 1000 population recommended World Health Organisation standard. On the credit front, other creditors such as China have contributed to prevailing economic challenges as China Official Development Assistance (ODA) to SSA debt ratio is depicted at 55\% in 2016 from a low ratio of $17 \%$ in 2009 . The economic challenges are further buttressed by estimated monthly tourism sector loss of US $\$ 8.8$ billion per month for SSA countries during the pandemic. SSA self-employed informal sector that accounts for 76\% (International Labour Organisation 2018) is equally affected amid lockdowns, business losses, closures and job losses. Economic growth is forecasted to drop to $1.8 \%$, from a previous estimate of 3.2\% according to United Nations Economic Commission (2020) due to a trade fall with developed and emerging markets. Recovery is aligned to good resilience in inherent cyber risk, oil intensity and urbanisation rate and policies to enhance production and the agriculture sector.
\end{abstract}

Keywords Coronoavirus $\cdot$ Economic $\cdot$ Impact $\cdot$ Sub-Sahara Africa

\section{Introduction}

This paper is motivated by the global spread of the coronavirus referred to as COVID-19 and its effect on Sub-Saharan African (SSA) economies. The International Monetary Fund (IMF) has alluded to the COVID-19 not only affecting the global health but also trade and tourism, commodity prices, and financial conditions that calls for an additional policy response to support demand and ensure an adequate supply of credit (IMF 2020a, b). Sub-Sahara African countries have equally been affected though infection cases are low compared to the epic centre Europe. To this effect, World Bank Group (WBG) and the International Monetary Fund (IMF)

Nchimunya Ndiili

bridgetndlli@yahoo.com

1 Lusaka, Zambia have availed financial support packages to help low income and emerging market countries in the prevention, detection and treatment of COVID-19. IMF availed about US\$50 billion through the Rapid-Disbursing Emergency Financing Facilities for low income and emerging market countries that needed financial support. As of 17th March, the World bank and International Finance Corporation (IFC) increased the financial aid to prevent, detect and treat COVID-19 to a tune of US $\$ 14$ billion of which US\$6 billion was marked for health measures and US $\$ 8$ billion to support private companies and their employees affected by the economic downturn caused by COVID-19 (World Bank 2020a, b). IFC's working capital facility will help banks continue lending to Small Medium Enterprises (SMEs) suffering from the economic fallout of the pandemic. However, access to IFC funds is based on credit, environmental and social governance and 


\section{Sub-Sahara Africa Transmission rate on confirmed cases}

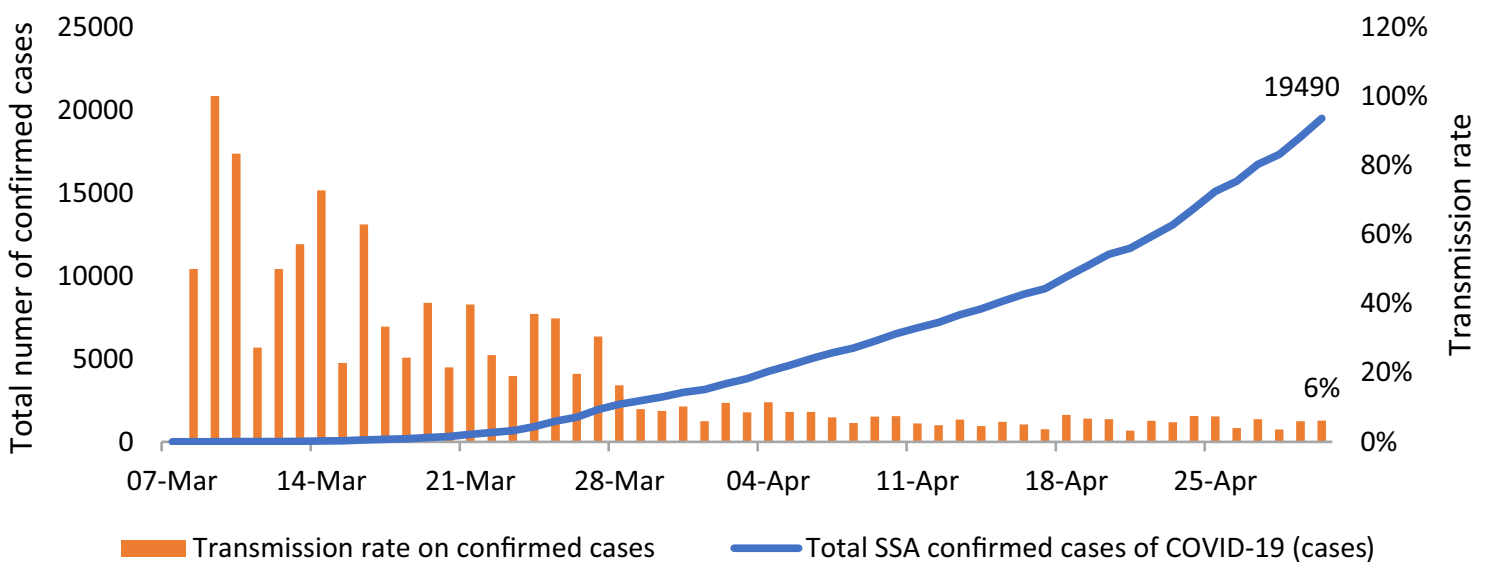

Fig. 1 Sub-Sahara Africa Transmission rate on confirmed cases. Source: Computed by Author, based on Ourworldindata

compliance criteria, as alluded by IFC. Hence, it is not a given that all countries will access these funds.

Further relief measures were instituted by WBG and the IMF to suspend debt payments from IDA countries that request forbearance. This is in attempt to help IDA countries with immediate liquidity needs to tackle challenges posed by the coronavirus outbreak (World Bank 2020a, b).

In this regard, the first section analyses the implemented pandemic preventive measures and underlying existing underlying economic challenges that are likely to impede WBG and IMF relief measures in SSA. The last section addresses Sub-Sahara Africa resilience to economic repercussions recovery. To evaluate SSA's resilience to the pandemic, resilience literature that is a new dimension in risk management is utilised. Applying the concept to the infancy stage of the pandemic in SSA with little quantitative information, the analysis is limited to the resilience process as well as employing the most recent historical index to project resilience during the pandemic.

\section{Sub-Saharan Africa countries pandemic preventive measures and underlying economic challenges amid COVID-19 relief packages}

Amid relief packages advanced to SSA countries by WBG and IMF, the countries have implemented social distancing measures to slow down transmission of the virus such as school closures, workplace non-attendance, increased case isolation, and community contact reduction. These measures have been effective in other parts of the world such as Australia according to Milne and Xie (2020) and collaborate with the declining transmission rate trajectory in SSA over time as shown in Fig. 1. With the first SSA case recorded in
Nigeria on the 28th of February and subsequent new cases in other countries, the initial local transmission in the region is noted in South Africa on 7 th of March at $100 \%$ rate. As at end of April, the transmission rate stood at a low of $6 \%$ despite having 19,490 confirmed cases in SSA. The decline in the transmission rate that commenced end of March coincides with the SSA government implementation of social distancing measures. This indicates an increase in the number of local transmitted confirmed cases at a slow pace at inception of social distancing measures implementation, end of March. With strict adherence to social distancing alongside other measures, the region may sustain low transmission rate and preventive spread in the congested townships.

With a $10 \%$ surge in the urban population from 1995 to 2020 , close to half of the population resides in the urban area as shown in Fig. 2a. The implies that urban townships are more susceptible to the exposure of the virus than rural areas given the high person per kilometre square occupancy as well as access to populated social amenities. According to the 2020 World meter data, Eastern Africa and Western Africa have the highest person per kilometre square occupancy in SSA, recorded at 67 persons per $\mathrm{km}^{2}$ and 66 persons per $\mathrm{km}^{2}$, respectively, as shown in Fig. 2b. Low person per kilometre square occupancy is recorded at 28 persons per $\mathrm{km}^{2}$ and 25 persons per $\mathrm{km}^{2}$ for Middle Africa and Southern Africa, respectively. Therefore, slackened adherence to social distancing may propel the virus spread to congested townships and the effect is likely to be more severe in SSA than confirmed cases in North America ${ }^{1}$ on account of

\footnotetext{
1 North America is utilised as a benchmark on account of having highest recorded cases; approximately 1.4 million confirmed cases in three major countries; United State of America, Canada, Mexico (Worldometer, 2020).
} 
Fig. 2 a, b, c Density (person per kilometre squared) occupancy. Source: Computed by Author, based on World meter data
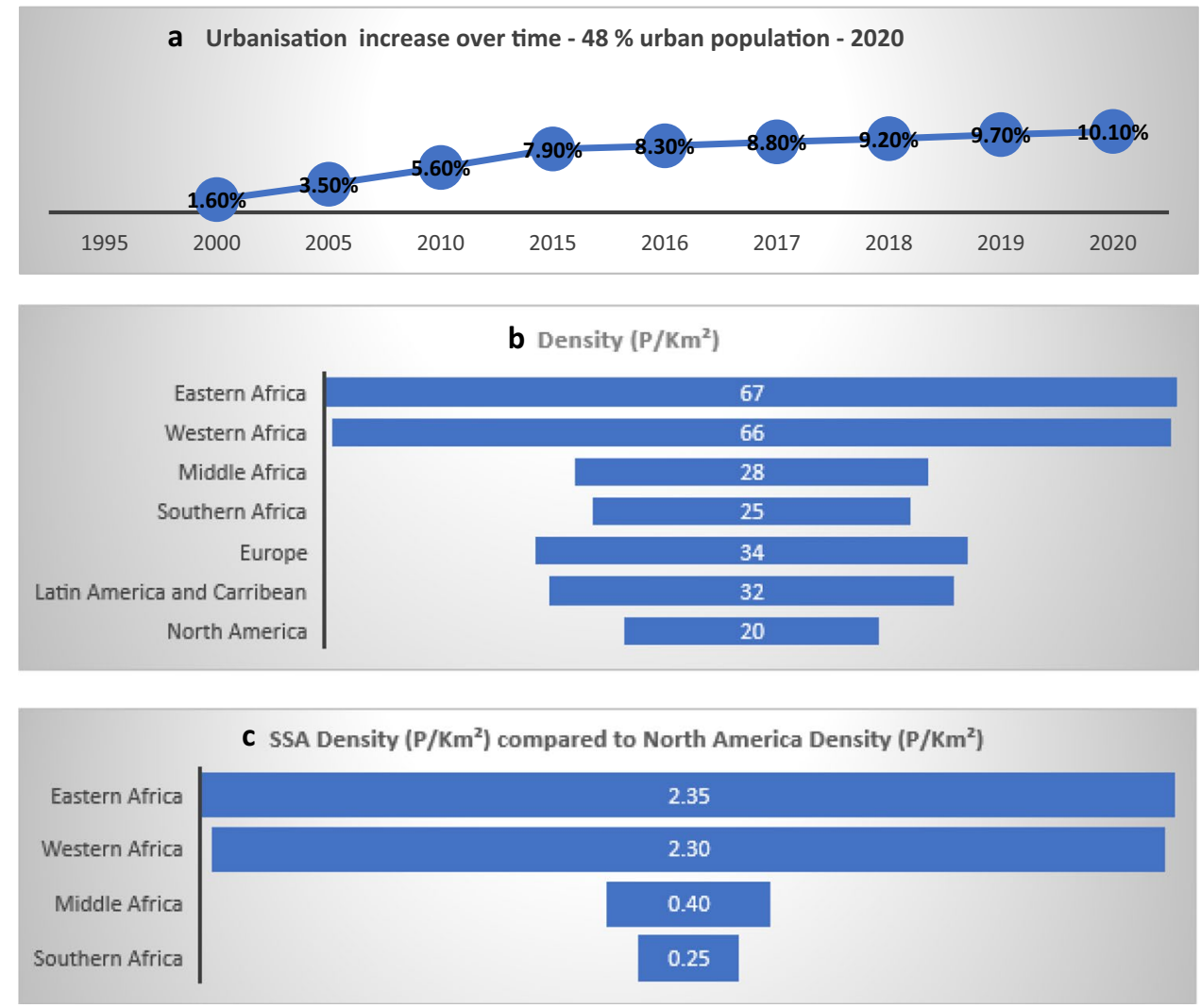

persons per km squared measure. Eastern Africa and Western Africa with 2.35 and 2.30 times more persons per $\mathrm{km}$ squared occupancy than North America density occupancy are likely to be the most affected part of SSA as shown in Fig. 2c. With the upward curve exhibited in Fig. 1, relaxing social distancing may enhance infection transmission and spread to congested townships.

There is a trade-off between social distancing, among other measures and stalled economic activities in SSA. To boost economic activities, most SSA governments have pronounced relief measures focusing on tax exemptions and business compensation. The heightened monetary demand has been cushioned by WBG and IMF relief packages. Despite the interventional measures instituted by WBG and IMF to cushion the economic downturn effect on SSA economies, countries face a high economic risk given the prevailing underlying health infrastructures and resource deficiency, unsustainable high debt levels and existing drought effects due to climate change. World Health Organization (WHO) recommended doctor-to-population ratio is 1:1000 (Kumar and Pal 2018). As of end 2015, WHO reported inadequate doctors in SSA that stood at less than 1 per 1000 population at a record of 0.2 per 1000 population. Restricting ranking of the inadequate doctor-to-population ratio levels from 2015 to 2017, South Africa with the highest ratio close to the WHO standard depicted 0.9 per 1000 , with the least of 0.0 per 1000 recorded for Somalia, Sierra
Leone, Liberia, Togo, Malawi, Chad and Tanzania. Most of the remaining countries fell in the 0.1 per 1000 population category such as Zambia, Zimbabwe, Uganda, Lesotho, Mozambique, Burundi, Burkina Faso, Cameron, Congo DR, Central republic, Eritrea, Swaziland, Ethiopia, Gambia, Guinea, Mali, Niger, Rwanda and Senegal as shown in Fig. 3 (World Bank 2020a, b). To meet the doctor demand, outsourcing is very unlikely given the global doctor challenge in all parts of COVID-19-affected countries but utilise available medical personnel.

Except for 2 virus free countries ${ }^{2}$ reported by African News on 9th of April, the rest of SSA countries exposed to COVID-19 are likely to be overwhelmed as infection numbers surge up given the prevailing inadequate doctorto-population ratio. Subsequently, distorting approved national budgets as national expenditure on the health sector demands more resources than other sectors to respond to the pandemic. The fiscal capacity adjustment is inevitable to address surgeon deficiency as well as develop emergency response infrastructure and procure required ventilators for extreme cases. Although the World Bank and IFC have floated emergency packages to cushion inadequate national expenditures to respond to the pandemic, not all SSA countries will access these funds as earlier stated based on credit,

\footnotetext{
$\overline{2}$ Comoros, Lesotho.
} 
Sub -Sahara African countries Doctor to 1000 population

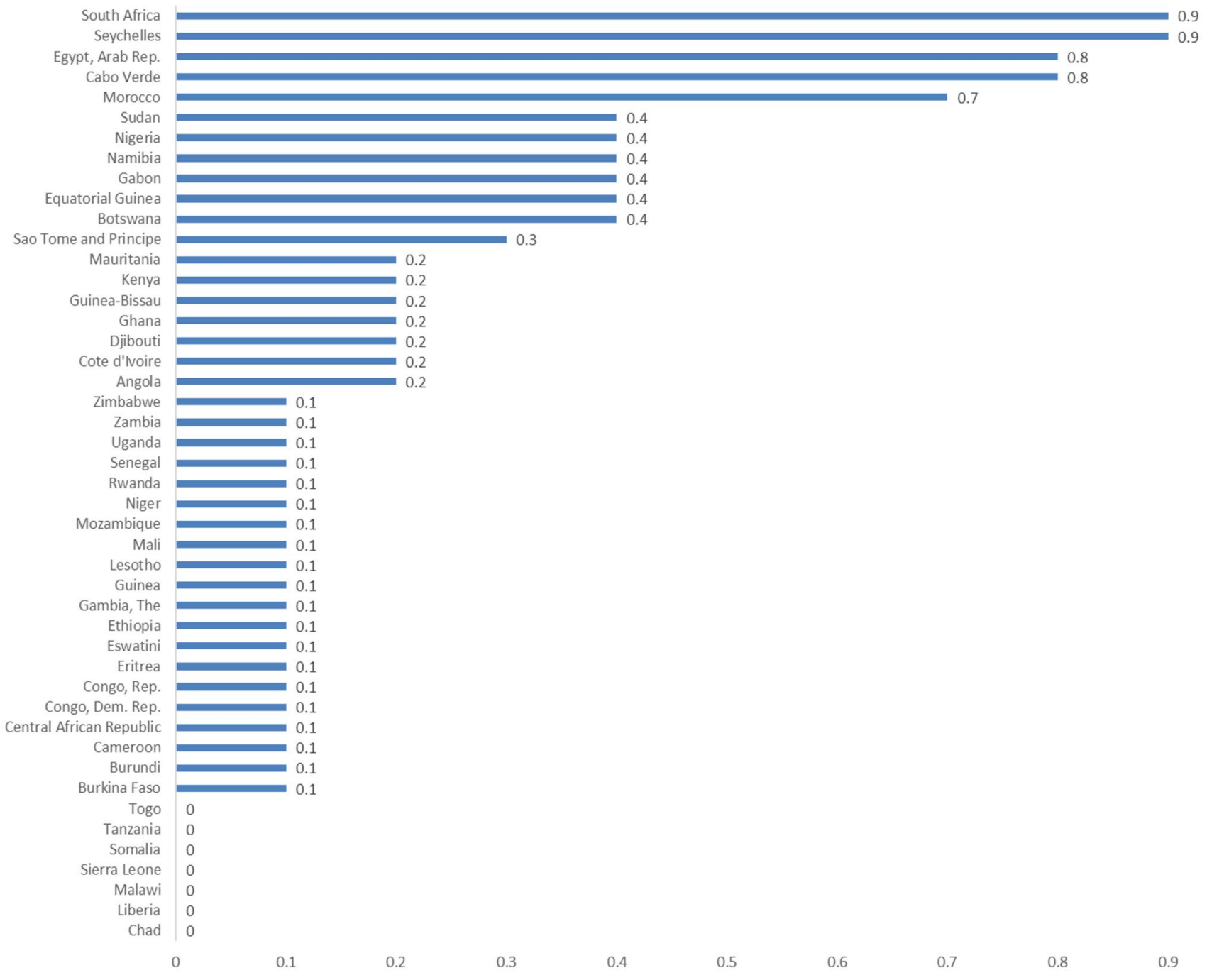

Fig. 3 SSA doctor per 1000 population ratio. Source: Computed by Author based on IMF database 2020, World Bank database 2020

environmental and social governance and compliance criteria to be applied.

Furthermore, debt repayment suspension for IDA countries instituted by WBG and IMF is only a guarantee of IDA countries having immediate liquidity but not necessarily adequate to tackle challenges posed by the coronavirus outbreak. The relief comes at a time when countries have other liquidity needs to address prevailing drought challenges that have led to massive power load shedding, low productivity and liquidity levels. High debt levels from other creditors such as China have also contributed to prevailing economic pressures as shown in Fig. 4. China's investments and loans loosely termed as Official Development Assistance (ODA) to SSA debt ratio stood at 55\% in 2016 from a low ratio of $17 \%$ in 2009. Liabilities solely to China account for over half of SSA debt which may encumber WBG and IMF's effort to avail IDA countries with immediate liquidity arising from debt repayment suspension.

SSA has also seen a surge in natural hazards due to climate change effects. The entire region is faced with droughts and hot temperatures that result in ecosystem damage, increased diseases such as malaria, deforestation, locust swarms particularly in Eastern African, poor crop harvest and migration of rural indigenous in search of better habitable areas (Lisk 2009). Seasonal floods are equally eminent that disrupt safe habitation as well as destroy agriculture produce. Coupled with the emergence of COVID-19 spread, this poses a threat on the region's economic growth.

Notwithstanding the prevailing economic challenges, COVID-19 has created more challenges eminent in the 


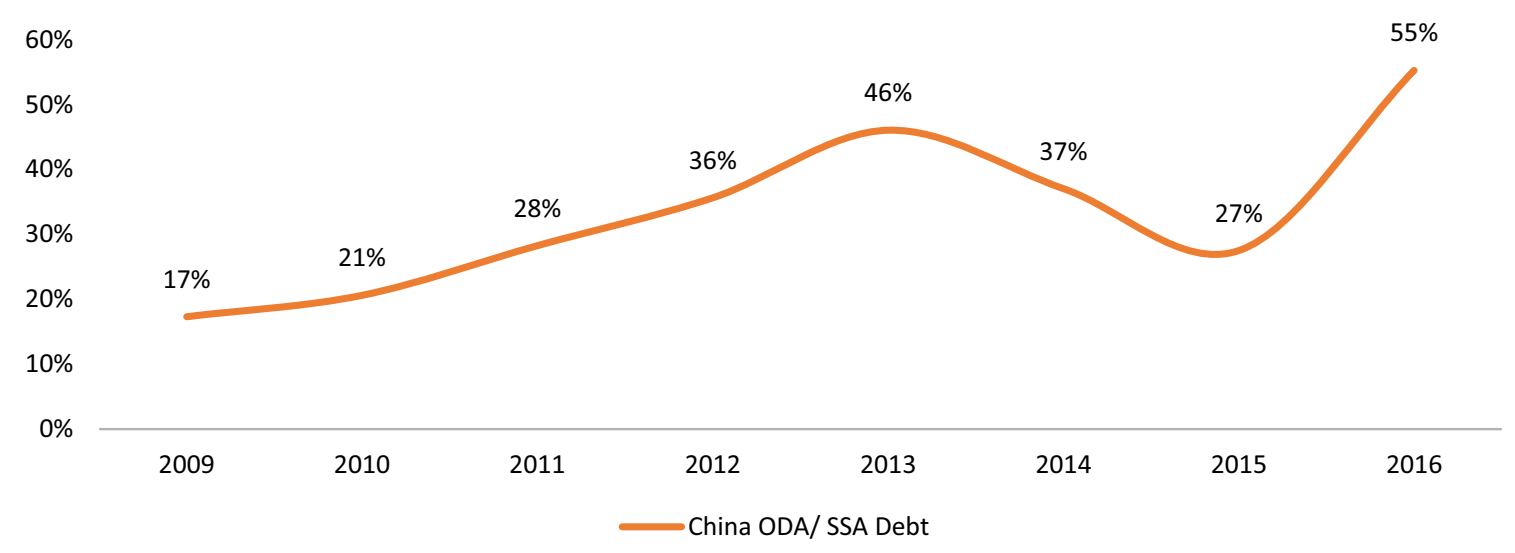

Fig. 4 China's investments and loans to Sub-Sahara Africa debt ratio. Source: Computed by Author, based on China's Africa Research Initiative 2017, IMF database 2020, World Bank database 2020, Aid data 2020

cross-border trade, tourism, production and household income and expenditure. Most of the SSA countries with COVID-19 have suspended cross-border mobility and trade. This reduces exposure to imported new infections but possess a disruption in supply chain for import-based countries. African countries are net food importers with an annual net food imports increase of $3.4 \%$ annually between 1980 and 2007 according to Rakotoarisoa et al. (2011). Climate change effects have not improved the net food import status according to Schuttenhelm (2018). Therefore, SSA countries with already prevailing negative agricultural productivity will have a further negative impact on both food supply and the economy due to border lockdowns.

The tourism sector that accounts for approximately $13 \%$ of SSA GDP as determined from the World Bank database is one of the negatively impacted sectors on account of cancelled international hotel bookings, safaris and flights. The likely estimated loss using the African Travel and Tourism Association (ATTA 2018) tourism GDP of US $\$ 194.2$ billion is US $\$ 16.18$ billion per month. Narrowing the analysis to SSA countries after excluding the North African countries that have a $4 \%$ tourism GDP, the estimated monthly loss is US $\$ 8.8$ billion per month for SSA given the ATTA $6 \%$ tourism contribution to GDP as shown in Fig. 5.

Production is equally affected as activities both in the formal and informal sector are suspended. The losses are yet to be established but these have direct link to government revenue deficit and expenditure, high cost of doing business and tight liquidity conditions in the economy. Prices for essential goods have notably surged up in some economies considering the scarcity of good supplies. For exceptional few companies still engaged in production, operations come at a cost as the restricted supply chains disrupt access to inputs. Hence, some regional stores have incurred losses and foreclosures, and subsequent job losses. An example is the closure of some stores for a renowned Southern Africa regional group clothes chain stores trading as Edcon Ltd, with stores such as Egdars, Jets and CNA. With already existing financial challenges, the pandemic has further stressed the company's financial position with a recorded moving annual negative earnings before interest and taxes (EBIT) of ZAR 21.3 million as at end of January 2020 in Zambia, according to the Lusaka Times (2020). The financial downturn led to Egdars and Jets store closures in Zambia as other outlets in Africa are under review.

Apart from the tourism sector being the most negatively affected by the pandemic, SSA self-employed informal sector that accounts for $76 \%$ (International Labour Organisation 2018 ) is equally the most vulnerable during the pandemic. Africa's informal sector is largely made up of own-account workers, these are individuals that do not hire others according to ILO. With the enforcement of mobility restriction and lockdowns, self-employed businesses, mainly street vendor businesses which are the source of their daily livelihood, incur losses. Subsequently, tightened liquidity amid a lock down has denied the majority $76 \%$ self-employed the ability to fern for themselves, most importantly fail to stock the

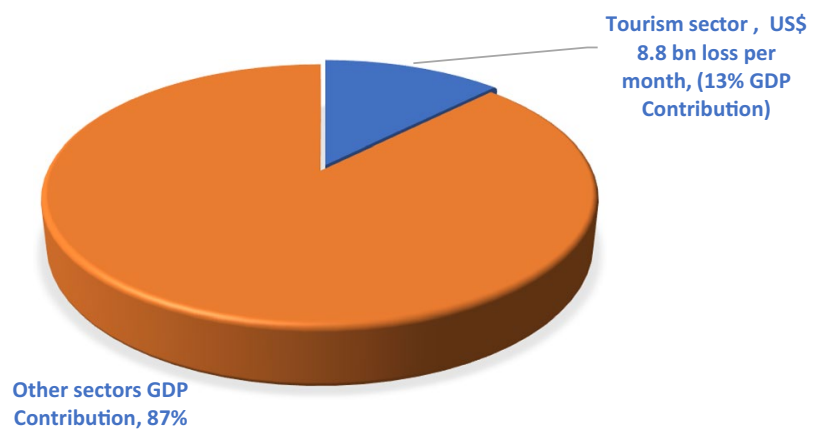

Fig. 5 Share of Sub-Saharan Africa tourism of GDP and estimated loss during lockdown. Source: Computed by Author, based on ATTA, 2018, World Bank database 
Fig. 6 Salient positive resilient factors. Source: Computed by Author, based on FM Global Resilience Index data

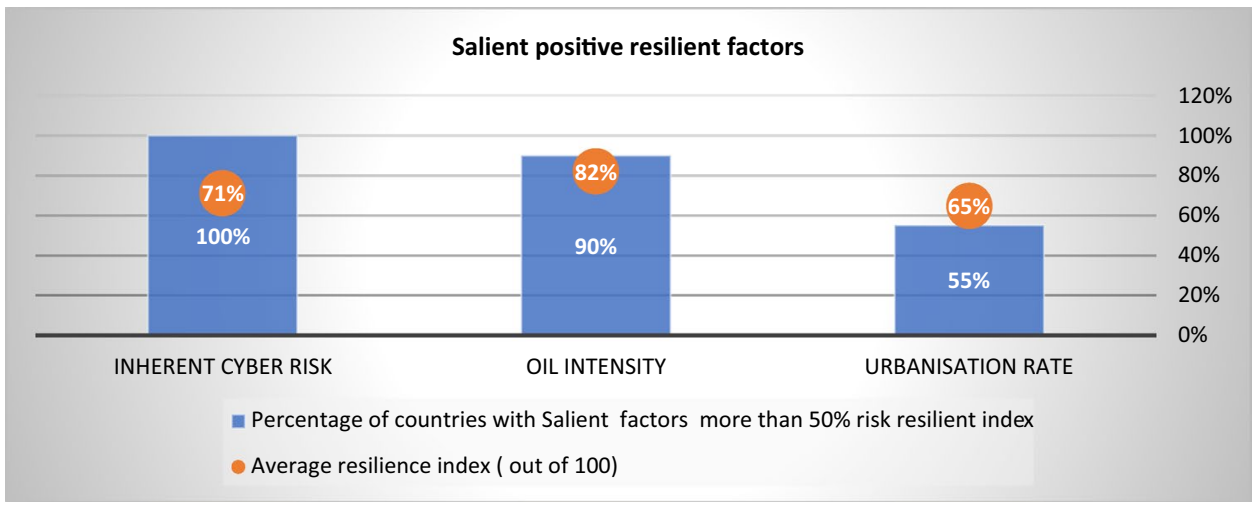

necessary essentials to last a lockdown period. Most governments have pronounced relief measures focusing on tax exemptions and business compensation. As of 7th of April, two countries, Rwanda and Zimbabwe extended relief packages to households, particularly the vulnerable who cannot stock essential to last the lockdown period. Zambia observer (2020) reported a Zimbabwean household relief package for 1 million vulnerable households and Rwanda's door to door free distribution of food and electricity to Rwandans and people living in Rwanda.

On the backdrop of the preceding negative impact of the COVID-19 on SSA economies, economic growth is forecasted to drop to $1.8 \%$, from a previous estimate of $3.2 \%$ according to United Nations Economic Commission (2020). On a global front, the economic downturn is buttressed by loss of export revenues in commodity export-based countries due to a trade fall with developed and emerging countries, particularly China. As at early April, trade fall led to currency depreciation for most of SSA currencies. The year to date currency depreciation according to African Markets for the most affected currencies was $49 \%$ for the Zimbabwean currency, 33\% for the Zambian Kwacha, 32\% for the South African Rand, 28\% for Namibian dollar and 15\%\% for the Botswana Pula. Subsequently, these will push up local inflation and trigger monetary policy and financial tightening. Furthermore, loan repayments on the rising dollar debt will surge to higher levels.

\section{Sub-Sahara Africa resilience to economic repercussions recovery}

Utilising the National Academy of Science resilience phases of planning, absorption, recovery and adaption as described by Linkov et al (2016), alternatively described as reliability, vulnerability, recovery and recovered state by Barker and Ramirez-Marquez (2016), resilience in the SSA case is analysed. Resilience is the capacity of complex systems of people and nature to withstand disturbance without shifting into an alternate regime, or a different type of system organised around different processes and structures (Holling 1973). It is also described as a process to ensure soft landing after a shock and prevent a lasting damage to a functionality (Linkov et al. 2016). From a 4-resilience stage, SSA is in the vulnerability stage on account of the increasing virus spread cases as shown in Fig. 1. Vulnerability concept, defined as the magnitude of system damage given the occurrence of a disruptive scenario (Jonsson et al. 2008), is applied to the COVID-19 pandemic. SSA region falls under the vulnerability phase as it is still vulnerable to the virus spread given the upward confirmed cases in Fig. 1 with a record of 19,490 cases as at end of April.

With regard to resilience in the established vulnerability stage, there are commended quantitative methods by researchers in assessing resilience with respect to various systems such as ecosystem (Allen et al. 2016), natural disasters (Bakkensen et al. 2016), urbanisation (Flax et al. 2016). Appallingly, the infancy stage of the COVID-19 spread in SSA avails little data to apply quantitative methods in assessing resilience. However, recent historical index is utilised to project resilience during the pandemic. The most recent 2019 FM Global Resilience Index that evaluates business resilience to disruption indicates good SSA resilience derived from inherent cyber risk, oil intensity and urbanisation rate with an average resilience index of 71,82 and $65 \%$, respectively, as shown in Fig. 6. As production inputs, the good resilience derived from inherent cyber risk, oil intensity and urbanisation rate will aid in boosting productivity during recovery.

With the prevalence of lockdowns and working from home status, scammers as well as hackers are likely to take advantage of heightened internet usage via different devices. SSA countries have put up necessary cyber safety and security measures to curb criminal activities as indicated in the $71 \%$ index. Therefore, the platform is safely being utilised to disseminate COVID-19 updates and measures as the situation unfolds. Further, the pandemic is likely to have negligible impact on energy usage as the amount of energy 
Fig. 7 Sub-Sahara Africa Presidential, National Assembly and local elections-2020, 2021.

Source: Computed by Author, based on Electoral Institute for Sustainable Democracy in Africa data
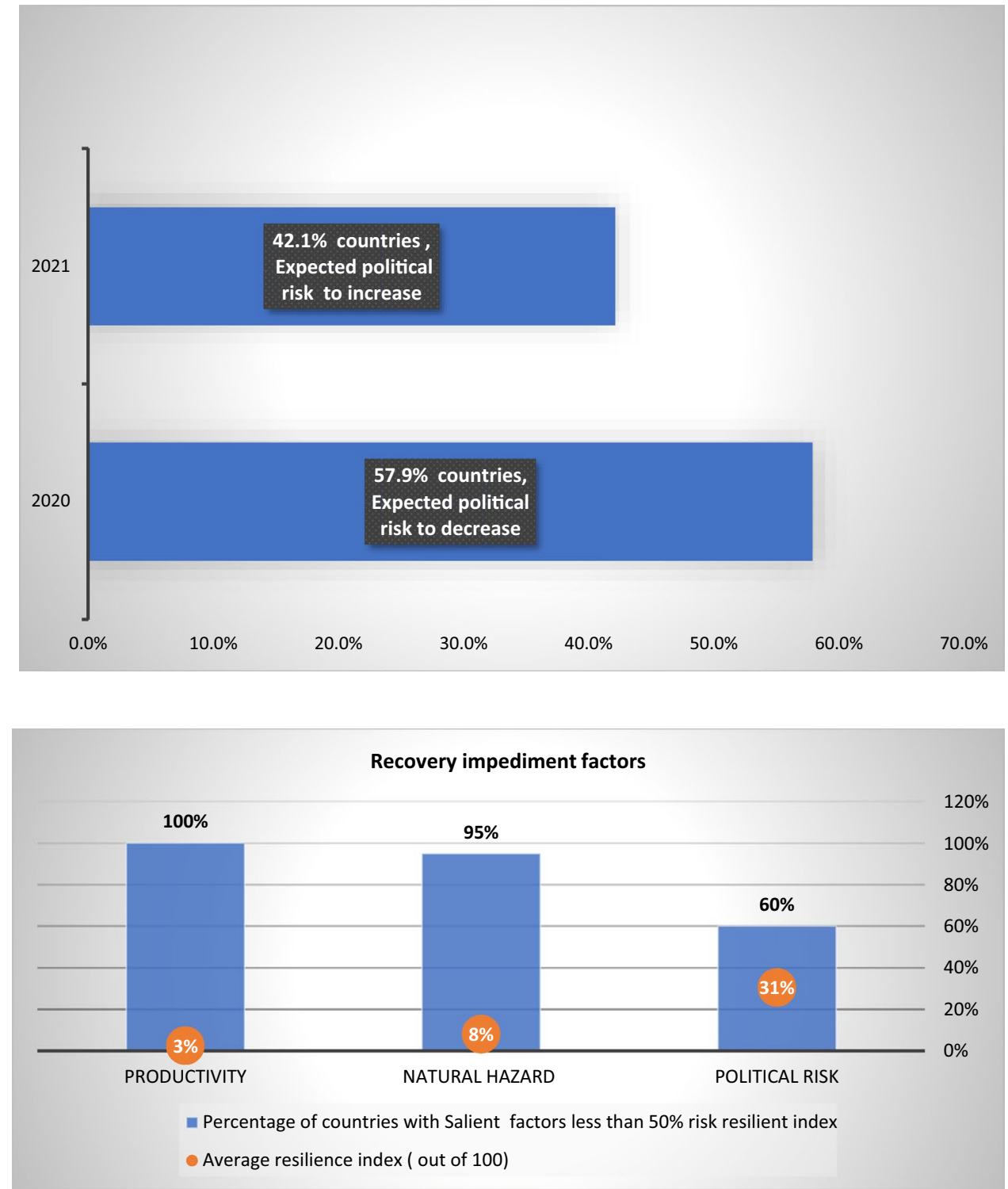

Fig. 8 Sub-Sahara Africa recovery impediment factors. Source: Computed by Author, based on FM Global Resilience Index data requirement in the production of exported products is low with a resilience record of $82 \%$, a position that has likely been heightened by low productivity due to lockdowns. This position is supported by the labour-intensive environment in the urban areas with resilience index of $65 \%$ arising from the $48 \%$ population residing in urban areas which is the hub of economic activities.

With developed countries relaxing lockdowns, international trade is expected to resume though at a slow pace until lockdowns are fully uplifted. Economic activities recovery in SSA export-based countries is expected to improve as global trade fully ensues. However, the pace to recovery is likely to be impeded by looming elections in the region with $57.9 \%{ }^{3}$

\footnotetext{
3 Angola, Burkina Faso, Burundi, Cameroon, Central African Republic, Chad, Comoros, Côte d'Ivoire, Ethiopia, Gabon, Ghana,
}

countries having either Presidential, National Assembly or local elections in 2020 with the rest ${ }^{4}$ of the country's elections scheduled for 2021 as shown in Fig. 7. With existing low political risk as shown in Fig. 8, political uncertainty will likely heighten among investors and subsequently stall investment as well as foster capital outflow. Hence, compromising on government revenues generated from investment

\section{Footnote 3 (continued)}

Guinea, Liberia, Malawi, Mali, Namibia, Niger, Tanzania, Senegal, Seychelles, Togo.

${ }^{4}$ Benin, Burkina Faso, Cape Verde, Central African Republic, Chad, Ivory Coast, The Gambia, Madagascar,

Mauritius, Morocco, Rwanda, São Tomé \& Príncipe, Seychelles, South Africa, Uganda, Zambia. 
ventures utterly needed to recover from government expenditure deficits incurred during the COVID-19 challenge.

In a stable state, productivity in the region is low with a resilience productivity index record of 3\% as shown in Fig. 8. Suspended production both in the formal and informal sector during the pandemic will worsen the position and extra effort to normalise productivity levels will be needed. Further, the net agriculture import position is likely to be enhanced given the interruption of supply chain due to crossborder lockdowns. Conversely, the net agriculture import position will be buttressed by poor local agriculture produce on account of seasonal floods and drought with a low resilience index record of $8 \%$ as shown in Fig. 8. Recovery will demand for SSA governments formulating policies that will enhance production and the agriculture sector, and subsequent boost economic activities. In the meantime, SSA government tax relief and business support packages are helping arrest significant shocks in the economies.

\section{Conclusion}

The severity of COVID-19 on SSA economies will be more evident in the medium term after the suspension of lockdowns and commencement of economic activities. At aggregate level, precise export revenue losses, government expenditure deficit, unemployment levels will determine the severity of the pandemic. Currently, the impact is perceptible in the tourism sector on account of cancelled international hotel bookings, safaris and flights. At a microlevel, restricted supply chains have disrupted access to inputs which has increased the cost of production, scarcity of essentials and a surge in prices. Business closures have resulted in job losses, low liquidity levels and compromised household consumption. The economic downturn will linger on in the medium term and will take government fiscal adjustments and reforms to curb the setbacks. Supported by good resilience derived from inherent cyber risk, oil intensity and urbanisation rate, formulated policies will have to enhance production and the agriculture sector to boost economic activities.

\section{Compliance with ethical standards}

Conflict of interest The author declares that there is no conflict of interest.

\section{References}

Acaps. https://www.Acaps.Org/Covid19-Government-Measures-Datas et. Accessed 6 May 2020.

Africa News. https://www.africanews.com/. Accessed 31 Mar 2020
African Markets. https://www.african-markets.com/en/tools/currencies . Accessed 3 Apr 2020

African Travel and Tourism Association (2019) An analysis of Africa's tourism market for April 2019. https://www.atta.travel/ news/2019/04/an-analysis-of-africas-tourism-market-for-april $-2019 /$. Accessed 31 Mar 2020

Aiddata. 2020

Allen CR, Garmestani AS, Sundstrom S, Angele DG (2016) Ecological Resilience. International Risk Governance Centre, pp 19-22

Bakkensen LA, Fox-Lent C, Read L, Linkov I (2016) Validating resilience and vulnerability indices in the context of natural disasters. International Risk Governance Centre. pp 23-28

Barker K, Ramirez-Marquez JE (2016) Infrastructure Network Resilience, International Risk Governance Centre, pp 29-35

Electoral Institute for Sustainable Democracy in Africa. https://www.eisa. org.za/calendar2020.php. Accessed 6 May 2020

Flax L, Armstrong A, Yee L (2016) Measuring urban resilience as you build it-insights from 100 resilient cities. International Risk Governance Centre, pp 47-53

FM Global Resilience Index. https://www.fmglobal.com/research-andresources/resources/resilienceindex

Health Workforce Statistics, OECD

Holling CS (1973) Resilience and stability of ecological systems. Annu Rev Ecol Syst 4:1-23

IMF (2020a) https://www.imf.org/external/np/fin/. Accessed 31 Mar 2020

IMF (2020b) IMF makes available $\$ 50$ billion to help address coronavirus, 4 Mar 2020

Jonsson H, Johansson J, Johansson H (2008) Identifying critical components in technical infrastructure networks. J Risk Reliab 222(2):235-243

Kumar R, Pal R (2018) India achieves WHO recommended doctor population ratio: a call. J Fam Med Prim Care 7(5):841-844

Linkov I, Trump BD, Fox-Lent C (2016) Resilience: approaches to risk analysis and governance. International Risk Governance Centre, pp $3-14$

Lisk F (2009) Climate Change in Africa: adaptation, mitigation and governance challenges. African Initiative Special Report, pp 8-15

Lusaka Times (2020) Over 270 jobs slashed as Edgars and Jets close shops in Zambia. https://www.google.com/amp/s/www.lusakatime s.com/2020/04/06/over-270-jobs-slashed-as-edgars-and-jets-close -shops-in-zambia/\%3famp. Accessed 6 Apr 2020

Milne GJ, Xie S (2020) The effectiveness of social distancing in mitigating COVID-19 spread: a modelling analysis. medRxiv. https://doi. org/10.1101/2020.03.20.20040055

Ourworldindata (2020) https://ourworldindata.org/grapher/full-list-cumul ative-total-confirmed-cases. Accessed 6 May 2020

Rakotoarisoa MA, Lafrate M, Paschali M (2011) Why has Africa become a net food importer? Explaining Africa Agriculture and food trade deficit. Food and Agriculture Organisation of UN, Rome

Schuttenhelm R (2018) Climate \& Agriculture African food imports increase, while agricultural dependence stays high. https://www. bitsofscience.org/african-food-imports-agriculture-dependence -7906/. Accessed 31 Mar 2020

World Bank (2020a) Joint Statement from the World Bank Group and the International Monetary Fund Regarding A Call to Action on the Debt of IDA Countries, 25 Mar 2020

World Bank (2020b) World Bank Group Increases COVID-19 response to $\$ 14$ billion to help sustain economies, protect jobs, 17 Mar 2020

World Bank. https://data.worldbank.org/indicator. Accessed 19 Jan 2020

Worldometer (2020) www.Worldometers.info. Accessed 6 May 2020

Zambia Observer (2020) Zim Govt to give 1 million families money during lockdown. https://www.zambiaobserver.com. Accessed 7 Apr 2020 